Research Article

\title{
Biocementation Influence on Flexural Strength and Chloride Ingress by Lysinibacillus sphaericus and Bacillus megaterium in Mortar Structures
}

\author{
Daniel Karanja Mutitu $\left(\mathbb{D},{ }^{1}\right.$ Jackson Muthengia Wachira ${ }^{D},{ }^{1}$ Romano Mwirichia, ${ }^{2}$ \\ Joseph Karanja Thiong'o, ${ }^{3}$ Onesmus Mulwa Munyao ${ }^{\mathbb{D}},{ }^{3}$ and Muriithi Genson ${ }^{2}$ \\ ${ }^{1}$ Department of Physical Sciences, University of Embu, Embu, Kenya \\ ${ }^{2}$ Department of Biological Sciences, University of Embu, Embu, Kenya \\ ${ }^{3}$ Department of Chemistry, Kenyatta University, Nairobi, Kenya \\ Correspondence should be addressed to Daniel Karanja Mutitu; mutsonjnr@gmail.com
}

Received 27 January 2020; Revised 2 April 2020; Accepted 27 April 2020; Published 28 May 2020

Guest Editor: Jorge Sanjurjo-Sánchez

\begin{abstract}
Copyright ( $\odot 2020$ Daniel Karanja Mutitu et al. This is an open access article distributed under the Creative Commons Attribution License, which permits unrestricted use, distribution, and reproduction in any medium, provided the original work is properly cited.
\end{abstract}

\begin{abstract}
The concrete/mortar durability performance depends mainly on the environmental conditions, the microstructures, and its chemistry. Cement structures are subject to deterioration by the ingress of aggressive media. This study focused on the effects of Bacillus megaterium and Lysinibacillus sphaericus on flexural strength and chloride ingress in mortar prisms. Microbial solutions with a concentration of $1.0 \times 10^{7}$ cells/ml were mixed with ordinary Portland cement (OPC $42.5 \mathrm{~N}$ ) to make mortar prisms at a water/cement ratio of 0.5. Four mortar categories were obtained from each bacterium based on mix and curing solution. Mortar prisms of $160 \mathrm{~mm} \times 40 \mathrm{~mm} \times 40 \mathrm{~mm}$ were used in this study. Flexural strength across all mortar categories was determined at the $14^{\text {th }}, 28^{\text {th }}$, and $56^{\text {th }}$ day of curing. Mortars prepared and cured using bacterial solution across all curing ages exhibited the highest flexural strength as well as the highest percent flexural strength gain. Lysinibacillus sphaericus mortars across all mortar categories showed higher flexural strength and percent flexural strength gain than Bacillus megaterium mortars. The highest percent flexural strength gain of $33.3 \%$ and $37.0 \%$ was exhibited by the $28^{\text {th }}$ and $56^{\text {th }}$ day of curing, respectively. The mortars were subjected to laboratory prepared $3.5 \%$ by mass of sodium chloride solution under the accelerated ion migration test method for thirty-six hours using a $12 \mathrm{~V}$ Direct Current power source after their $28^{\text {th }}$ day of curing. After subjecting the mortar cubes to $\mathrm{Cl}$ media, their core powder was analyzed for $\mathrm{Cl}$ content. From these results, the apparent diffusion coefficient, $D_{\text {app }}$, was approximated from solutions to Fick's $2^{\text {nd }}$ Law using the error function. Bacillus megaterium mortars across all mortar categories showed lower apparent diffusion coefficient values with the lowest being $2.6456 \times 10^{-10}$ while the highest value for Lysinibacillus sphaericus mortars was $2.8005 \times 10^{-10}$. Both of the test bacteria lowered the ordinary Portland cement Cl-ingress but Bacillus megaterium was significantly more effective than Lysinibacillus sphaericus in inhibition.
\end{abstract}

\section{Introduction}

The durability of concrete/mortar is related to the characteristics of its pore structure [1]. Furthermore, permeability of concrete/mortar is dependent on the porosity and the connectivity of the pores $[2,3]$. The degradation mechanisms often depend on the way potentially aggressive substances can penetrate the cement-based material, possibly causing damage [4]. The more open the pore structure and connectivity of the pores, the more vulnerable it is to degradation caused by penetrating substances $[5,6]$.

One of the predominant causes of the corrosion of steel in cement-based structures is chloride attack [7-9]. Chloride ions may be present in a cementitious material either as a result of aggressive ions ingress or incorporation of the aggressive ions during concrete/mortar preparation. 
Chloride ions may also penetrate from external sources such as seawater or deicing salts. In the marine environment, the ingress of chloride is the most important problem $[10,11]$.

Chloride is bound if it has reacted with cement and is free if it is available in pore solution [10]. Several chemical interactions between chloride and the cement constituents do affect the chloride penetration into the concrete/mortar bulk $[5,12]$. The chemical reactions of chlorides with cement paste start with calcium hydroxide and calcium aluminate hydrate, depending on the cations in solution [13].

Chloride ingress in cement-based materials is mainly through capillary absorption, permeation, and diffusion [14]. However, it may also occur through a multiple of the aforementioned mechanisms. Diffusion is the most prevalent process [15]. The ingress of chlorides/sulphates due to the various transport mechanisms obeys different laws [16]. Fick's second law of diffusion is commonly applied to quantify the aggressive ion ingress due to the multiple transport phenomena.

Chlorides react with $\mathrm{C}_{3} \mathrm{~A}$ and the $\mathrm{C}_{4} \mathrm{AF}$ present in Portland cement to produce Friedel's salt, $\mathrm{Ca}_{6} \mathrm{Al}_{2} \mathrm{O}_{6} \cdot \mathrm{CaCl}_{2} \cdot 10 \mathrm{H}_{2} \mathrm{O}$, or calcium chloroferrite, $\mathrm{Ca}_{6} \mathrm{Fe}_{2} \mathrm{O}_{6} \cdot \mathrm{CaCl}_{2} \cdot 10 \mathrm{H}_{2} \mathrm{O}$, respectively $[5,14]$. No deleterious effect is associated with these products. The reaction between the $\mathrm{C}_{3} \mathrm{~A}$ phase and free chlorides in hydrated cement leads to a reduction of $\mathrm{Cl}^{-}$ from the pore solution [17]. This lowers the risk of rebar corrosion [18]. Solutions with high concentrations of $\mathrm{CaCl}_{2}$ or $\mathrm{MgCl}_{2}$ may cause chemical attack which may lead to a drop in pore water $\mathrm{pH}$ and disruption of the cement matrix [19]. This is due to the consumption of the sparingly soluble $\mathrm{Ca}(\mathrm{OH})_{2} . \mathrm{MgCl}_{2}$ reacts with portlandite as shown in

$$
\begin{aligned}
\mathrm{MgCl}_{2}(\mathrm{aq})+\mathrm{Ca}(\mathrm{OH})_{2}(\mathrm{~s})+2 \mathrm{H}_{2} \mathrm{O}(\mathrm{l}) \longrightarrow & \mathrm{CaCl}_{2} \cdot 2 \mathrm{H}_{2} \mathrm{O}(\mathrm{aq}) \\
& +\mathrm{Mg}(\mathrm{OH})_{2}(\mathrm{~s})
\end{aligned}
$$

Biocementation in OPC lowers chloride ingress and permeability into the cement matrix [20]. This is due to the refinement of the pore structure [5]. Chloride ions penetrate a pore system and form chloride salts which may crystallize within the pores inducing internal cracks [21]. The cracks affect the mechanical and durability properties of concrete/ mortar [20, 22, 23].

The high alkalinity of the concrete/mortar introduced during the bacteria MICP prevents the breakup of the passive film $[25,24]$. Its carbonation accompanied by the presence of chloride ions lowers the alkalinity of pore water. Rasheeduzafar et al. [18], Dousti et al. [21], and Rao and Meena [26] observed the amount of free chloride decrease with increasing $\mathrm{C}_{3} \mathrm{~A}$ and the amount of bound chloride decreased with increasing $\mathrm{OH}$-concentration from the cement. Given this, the high corrosion of rebars exposed to chloride media can be assumed to be due to the low alkalinity of pore solution $[21,22,27]$.

OPC based structures are well known for achieving high early compressive and flexural strength due to large content and early hydration of $\mathrm{C}_{3} \mathrm{~S}[15,28,29]$. Despite the various OPC concrete/mortar advantages, it has a more open pore structure than blended cement structures [3, 15, 30]. OPCmade structures also have a high tendency to form cracks during and after curing allowing aggressive substances to penetrate the structure. Permeability or cracks are one of the main causes of deterioration of these structures and decrease in durability. Treatment of cracks and pores are generally divided into passive and active treatments. Passive treatments can only heal the surface cracks, while active treatments can heal both interior and exterior cracks $[22,25]$.

Microbial concrete/mortar biologically produce calcium carbonate (limestone) to seal pores that appear within its matrix or seal/repair cracks that appear on the structure's surface $[25,31]$. These microbial deposits could also establish nucleation sites that enhance the early cement hydration process leading to improved compressive and flexural strengths. Microbial precipitation of calcium carbonate mainly occurs by hydrolyzing urea. Urea hydrolysis is a chemical reaction in which urea reacts with water and produces ionic products as shown in the following equation:

$$
\mathrm{CO}\left(\mathrm{NH}_{2}\right)_{2}+2 \mathrm{H}_{2} \mathrm{O} \underset{\longrightarrow}{\longrightarrow} \mathrm{CO}_{3}{ }^{2-}+\mathrm{NH}_{4}{ }^{1+}
$$

When this reaction occurs in the presence of $\mathrm{Ca}^{2+}$, $\mathrm{CaCO}_{3}$ (solid) is formed as shown in the following equation:

$$
\mathrm{Ca}^{2+}+\mathrm{CO}_{3}^{2-} \longrightarrow \mathrm{CaCO}_{3}
$$

When this reaction occurs inside a cementitious porous material, after settling, it produces sediment, a coating, and a bridge is formed sequentially around and between the particles and increases interparticle linkage [31].

Specific types of the bacteria genus such as Bacillus along with a calcium-based nutrient, such as calcium lactate, or calcium nitrate could be added to the ingredients of the concrete/mortar when it is being mixed [21]. The soluble calcium-containing nutrient is converted to insoluble calcium carbonate $[22,32]$. The calcium carbonate solidifies on the cracked surface, thereby sealing it up.

The densification of cementitious material due to microbial reaction is important in reducing the permeability of aggressive ions. This paper reports on findings of the flexural strength gain of MICP-containing Kenyan-made OPC and lowered diffusivity of chloride in such laboratory-made mortars.

\section{Materials and Methods}

2.1. Cement Chemical Analysis. In this study, the ordinary Portland cement (OPC 42.5 N), KS EAS 18-1:2017 [33], and standard sand, ISO 679:1989 [34], were used. Flexural strength tests were carried out in accordance to ASTM C293: 1990 [35]. $100 \mathrm{~g}$ sample of the test cement sample was prepared and analyzed in the usual manner following KS EAS 18-1:2017 [33]. Loss on ignition was done following ASTM D7348: 2013 [37]. The results are given in Table 1.

Using Bogues formula [36], the average phase composition for the test OPC is $65.115 \pm 0.854 \%, 14.485 \pm 0.913 \%$, $3.899 \pm 0.013 \%$, and $10.355 \pm 0.018 \%$ for $\mathrm{C}_{3} \mathrm{~S}, \mathrm{C}_{2} \mathrm{~S}, \mathrm{C}_{3} \mathrm{~A}$, and $\mathrm{C}_{4} \mathrm{AF}$, respectively. 


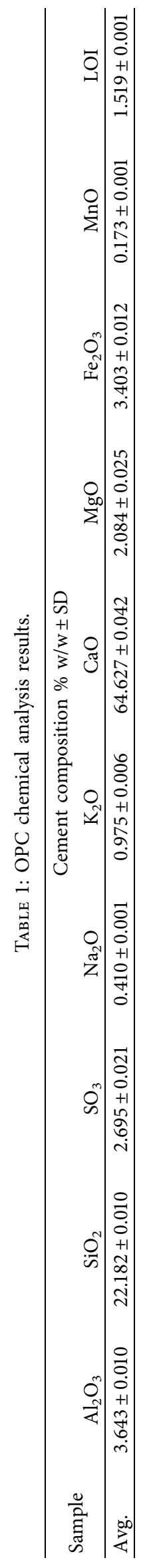


2.2. Microbial Culturing Nutrients. Analytical grade chemicals were used in the preparation of the culture media. Calcium lactate, $\mathrm{C}_{6} \mathrm{H}_{10} \mathrm{O}_{6} \mathrm{Ca}$, peptone from casein and other animal proteins, meat extract, agar, sodium hydrogen carbonate $\left(\mathrm{NaHCO}_{3}\right)$, anhydrous sodium carbonate $\left(\mathrm{Na}_{2} \mathrm{CO}_{3}\right)$, and distilled water among other nutrients were purchased from Chem-Labs Limited, Nairobi, Kenya. Lysinibacillus sphaericus bacteria (DSM 28) and Bacillus megaterium (DSM 32) were purchased from Leibniz-Institut DSMZDeutsche Sammlung von, Germany.

2.2.1. Lysinibacillus sphaericus Microbial Culturing. The Lysinibacillus sphaericus microbial solution was cultured using nutrients as per the supplier manual. The liquid medium chosen for culturing the bacteria consisted of $5.00 \mathrm{~g}$ of peptone added to $3.00 \mathrm{~g}$ of meat extract and $3.95 \mathrm{~g}$ of calcium acetate per liter of distilled water was mixed to obtain liquid medium per stock culture. Initially, this mixture was sterilized for 20 minutes at a temperature of $121^{\circ} \mathrm{C}$ by autoclaving. This mixture was then cooled to room temperature. After cooling, a $1 \mathrm{M} \mathrm{Na-sesquicarbonate} \mathrm{so-}$ lution $(1.0 \mathrm{ml}$ in $10.0 \mathrm{ml})$ prepared by mixing $4.2 \mathrm{~g} \mathrm{NaHCO}_{3}$ with $5.3 \mathrm{~g}$ anhydrous $\mathrm{Na}_{2} \mathrm{CO}_{3}$ and made up to 1 liter using distilled water was added to the stock culture to achieve a $\mathrm{pH}$ of 9.7. The Lysinibacillus sphaericus spore powder sample was added to this mixture in a laminar flow chamber. These cultures were then incubated on a shaker incubator at 130 shakes per minute maintained at $30^{\circ} \mathrm{C}$ for 72 hours. An optical density test was conducted using a spectrophotometer for determining the quantity of culture solution required to mix. This test was conducted in bacteria growing medium which was considered as blank. This solution was also taken to be the reference, for experimentation of optical density of the microbial solution. Separately, $0.5 \mathrm{~mL}$ of blank and bacteria solution of $0.5 \mathrm{~mL}$ were placed in the spectrophotometer at a wavelength of $600 \mathrm{~nm}$ and the machine was set to read. The microbial concentration was observed to be $1.0 \times 10^{7}$ cells $/ \mathrm{mL}$ using the spectrophotometer. This microbial culture concentration was maintained throughout the mortar samples preparation as well as in prism curing solution.

2.2.2. Bacillus megaterium Microbial Culturing. The Bacillus megaterium microbial solution was cultured using nutrients as per the supplier manual. The same procedure and nutrients as used in preparing the Lysinibacillus sphaericus microbial solution were used in preparing the Bacillus megaterium microbial solution. The Bacillus megaterium spore powder sample was added instead of Lysinibacillus sphaericus.

Figure 1 shows (a) OPC mortar prepared and being cured in distilled water, (b) OPC mortar prepared using Bacillus megaterium solution but being cured in distilled water, (c) OPC mortar prepared using distilled water but being cured in Bacillus megaterium solution and (d) OPC mortar prepared and being cured in Bacillus megaterium solution.
2.3. Mortar Prism Molding and Flexural Strength Testing. Mortar mix prisms were fabricated according to KS EAS 18-1:2017 [33]. $450 \mathrm{~g}$ of OPC was placed in the mixing basin of an automatic programmable mixer model number JJ-5. $225.0 \mathrm{ml}$ of distilled water was then added. The mix basin and its contents were clamped onto the automatic programmable mixer and allowed to run for three minutes. $1350 \pm 5 \mathrm{~g}$ of the standard sand was placed in an automatic pour-trough and allowed to add automatically, until all $1350 \pm 5 \mathrm{~g}$ sample was added while the mixer was still running at a speed of 30 vibrations per minute. The machine was let to run for ten minutes. The mortar prepared had $\mathrm{w} / \mathrm{c}$ ratio of 0.5 and was sufficient to prepare three mortar prisms. Once the mortar was mixed, it was poured into steel molds of $40 \mathrm{~mm} \times 40 \mathrm{~mm} \times 160 \mathrm{~mm}$. Using a trowel, the mortar paste was scooped from the automatic programmable mixing basin and placed in a compaction mold of a jolting compaction machine with $60 \mathrm{rpm}$ vibrations. Leveling of the paste was done with a mold trowel in each of the three chambers of the mold after every jolting cycle until a good finish was achieved at the surface. The mold with the mortar paste was then placed in a humid chamber maintained at $95 \%$ humidity and $27.0^{\circ} \mathrm{C}$ for 24 hours. The mortar was then removed from the molds after 24 hours to obtain the usual OPC mortar. The distilledwater prepared mortars were categorized into two categories depending on their curing regime. The first category was cured in distilled water (labeled as OPC- $\mathrm{H}_{2} \mathrm{O}\left[\mathrm{H}_{2} \mathrm{O}\right]$ ). The second category was cured in microbial solution (labeled as $\mathrm{OPC}-\mathrm{H}_{2} \mathrm{O}$ [LB] for Lysinibacillus sphaericus and $\mathrm{OPC}-\mathrm{H}_{2} \mathrm{O}$ [BM] for Bacillus megaterium). The above procedure was repeated but this time using $225 \mathrm{ml}$ of the microbial solution as mix media instead of distilled water which resulted in two more mortar categories (referred to as the third and fourth category): the third category was the OPC mortar prepared using the microbial solution and cured in distilled water (labeled as OPC-LB $\left[\mathrm{H}_{2} \mathrm{O}\right]$ Lysinibacillus sphaericus and OPC-BM $\left[\mathrm{H}_{2} \mathrm{O}\right]$ for Bacillus megaterium), while the fourth category was the OPC mortar prepared using the microbial solution and cured in microbial solution (labeled as OPC-LB [LB] for Lysinibacillus sphaericus and OPC-BM [BM] for Bacillus megaterium). The mortars were placed in requisite water or microbial solution for curing in a chamber maintained at $27 \pm 1^{\circ} \mathrm{C}$ for curing. The flexural strength tests were conducted at the $2^{\text {nd }}, 7^{\text {th }}, 14^{\text {th }}, 28^{\text {th }}$, and $56^{\text {th }}$ day of curing. Flexural strength tests in this study were performed on three samples per category for obtaining average results.

2.4. Scanning Electron Microscopy (SEM) Sample Preparation and Analysis. SEM analysis was determined for each set of test mortars after the $28^{\text {th }}$ day of curing. The SEM model used was Zeiss Ultra Plug FEG-SEM. The test mortar was prepared for SEM analysis as described in Scrivener et al.'s [38] guide for microstructural analysis of cementitious materials as summarized in Figure 2. Isopropanol alcohol was used to stop the hydration process while resin ERL-4206 was used to impregnate the hardened cement mortar. 


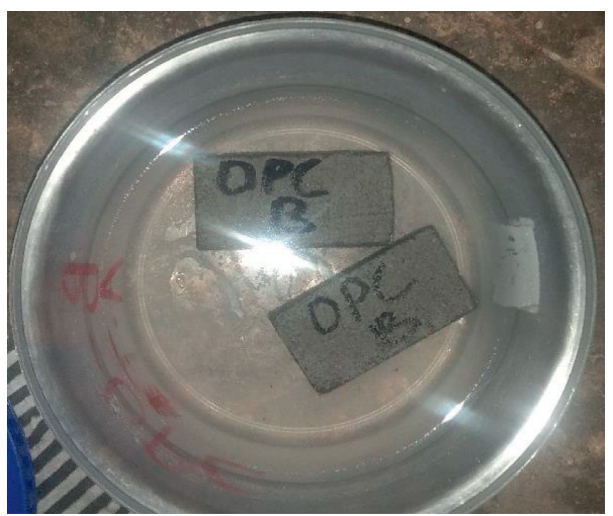

(a)

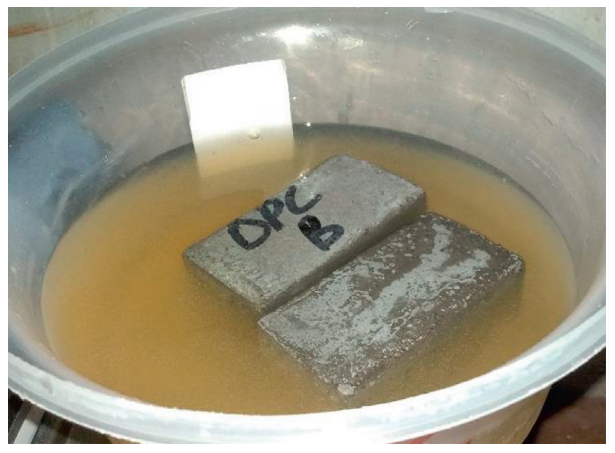

(c)

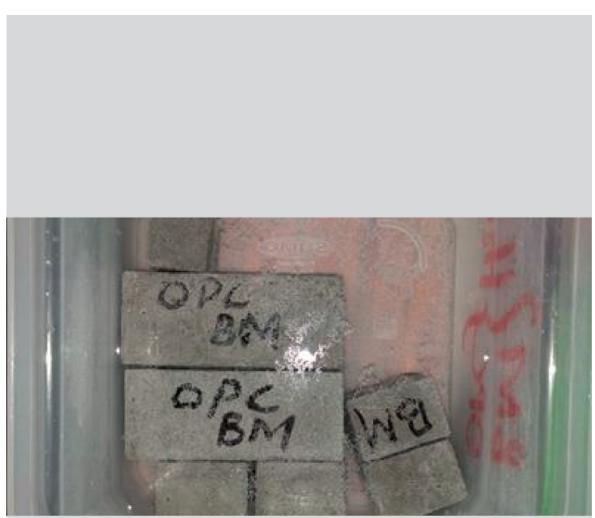

(b)

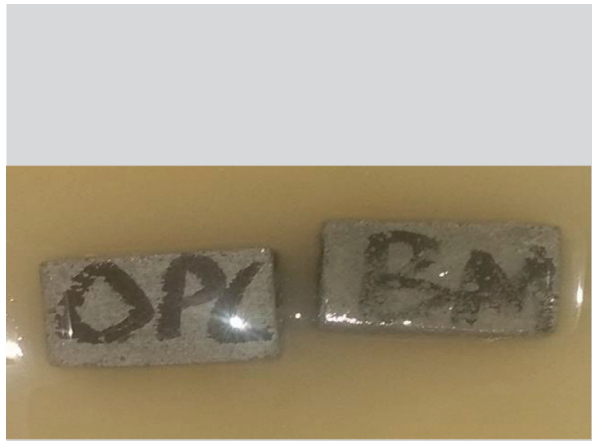

(d)

Figure 1: Cement mortar curing in varied regimes. (a) OPC- $\mathrm{H}_{2} \mathrm{O}\left[\mathrm{H}_{2} \mathrm{O}\right]$. (b) OPC-BM $\left[\mathrm{H}_{2} \mathrm{O}\right]$. (c) OPC- $\mathrm{H}_{2} \mathrm{O}[\mathrm{BM}]$. (d) OPC-BM $[\mathrm{BM}]$.

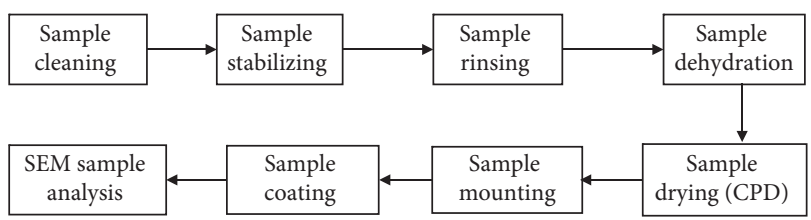

FIGURE 2: SEM sample preparation.

2.5. X-Ray Diffraction (XRD) Analysis. XRD analysis was determined for each set of test mortars after the $28^{\text {th }}$ day of curing. The mineralogy of the newly formed cement hydration/bacterial material was determined using an X-Ray Diffraction (XRD) Instrument PW1710 Phillips. Before running the $\mathrm{XRD}$ analysis samples were oven-dried at $100^{\circ} \mathrm{C}$ and powdered with an electronic grinder. They were then placed in a zero-background silicon sample holder. The goniometer was calibrated using a silicon standard. Samples were analyzed using PANalytical software, with goniometer start and end angles at 5.00 and $80.002^{\circ}$ Theta, step size of $0.0202^{\circ}$ Theta, and scan step time of 0.5 seconds at an adjusted current and voltage of $40 \mathrm{~mA}$ and $35 \mathrm{kV}$. respectively.

2.6. Chloride Ingress. For each category of mortar, three prisms, cured for 28 days, were subjected to chloride profiling using the method prescribed in ASTM C 1552 [39]. After the $\mathrm{NaCl}$ solution exposure, a mortar prism was polished on the $40 \mathrm{~mm} \times 40 \mathrm{~mm}$ face using sandpaper. The prism was drilled through the core center up to $10 \mathrm{~mm}$ interval along the length using a $15 \mathrm{~mm}$ radius drill bit up to $80 \mathrm{~mm}$ per mortar category. The powder was dried to a constant mass in an oven at $105^{\circ} \mathrm{C}$. The dried powder was pulverized. Between each pulverization, the pulverizer was thoroughly cleaned to avoid cross-sample contamination. The ground samples were kept in individual-sample sealed reagent bottles awaiting chloride analysis.

2.6.1. Chloride Profiling. The chlorides at each depth of penetration were analyzed using Mohr titration procedure in all the mortar categories. The estimation of apparent chloride diffusion coefficients was achieved under nonsteady state conditions assuming boundary conditions $\mathrm{C}_{(x, t)}=0$ at $t=0,0<x<\infty, \mathrm{C}_{(x, t)}=C_{\mathrm{s}}$ at $x=0,0<t<\infty$, constant effects of coexisting ions, linear chloride binding, and one-dimensional diffusion into semi-infinite solid [16]. Crank's solution to Fick's second law of diffusion is given by

$$
C_{(x, t)}=C_{(s)}\left\{1-\operatorname{erf}\left(\frac{x}{\left(4 D_{\mathrm{app}} t\right)^{(1 / 2)}}\right)\right\},
$$

where $C_{(x, t)}$ is the concentration of $\mathrm{Cl}^{-}$at any depth $x$ in the mortar bulk at time $t, C_{\mathrm{s}}$ is the surface concentration, and $D_{\text {app }}$ is the apparent diffusion coefficient. The error correction function, erf, is the Gaussian error function obtained from computer spreadsheets. The chloride profiles were obtained by fitting equation (4) to experimentally 
determined chloride profile concentrations, thus determining the values of $D_{\text {app }}$ and $C_{\text {s }}$ mathematically.

By using the accelerated migration diffusion coefficient $D_{\text {mig }}$ determined graphically, $D_{\text {app }}$ can be determined by using the following equation [40]:

$$
D_{\text {app }}=\frac{R T}{\mathrm{zi} F} D_{\mathrm{mig}} \frac{\mathrm{Int}^{2}}{\Delta \varnothing},
$$

where $R$ is the Gas constant, $F$ is the Faraday constant, $T$ is the temperature of the electrolyte in $\mathrm{K}$, zi is the valency of the ion $\mathrm{i}, \Delta \varnothing$ is the Effective Applied Voltage in $\mathrm{V}$, and $t$ is the duration of the test/exposure in seconds.

\section{Results and Discussion}

3.1. Scanning Electron Microscope (SEM) Analysis. Figures 3(a)-4(c) show SEM analysis for both control and microbial mortar prisms after the $28^{\text {th }}$ day of curing. The SEM images display the formation of calcium-silicate-hydrate, C-S-H, calcium carbonate precipitation, $\mathrm{CaCO}_{3}$, needle type ettringite, and presence of portlandite/calcium hydroxide, $\mathrm{CH}$.

As SEM images in Figure 3(a) illustrate, the $\mathrm{OPC}-\mathrm{H}_{2} \mathrm{O}$ $\left(\mathrm{H}_{2} \mathrm{O}\right)$ mortar had no visible calcium carbonate deposits. However, the SEM images in Figures 3(b)-3(d) as well in Figures 4(a)-4(c), the microbial mortars $\mathrm{OPC}-\mathrm{H}_{2} \mathrm{O}(\mathrm{LB})$, OPC- $\mathrm{H}_{2} \mathrm{O}(\mathrm{BM})$, OPC-LB $\left(\mathrm{H}_{2} \mathrm{O}\right)$, OPC-BM $\left(\mathrm{H}_{2} \mathrm{O}\right)$, OPC-LB (LB), and OPC-BM (BM) showed significant calcium carbonate precipitates. This is attributed to the MICP deposits from both Lysinibacillus sphaericus and Bacillus megaterium either present in mix media or present in the cultured curing solution $[1,41]$. The morphology of C-S-H densifies from Figure 3(b) through Figures $3(\mathrm{c})-3(\mathrm{~d})$ as well as from Figure 4(a) through Figures $4(\mathrm{~b})-4(\mathrm{c})$. This is attributed to the calcium carbonate precipitation by the two bacteria under study. Image (c) from Figure 3, clearly shows biodeposition over ettringite needles resulting in the formation of biofilms on their surface and plugging of the pores on the mortar structure.

3.2. X-Ray Diffraction Analysis (XRD). Table 2 shows XRD analysis results for both control and microbial mortar prisms after the $28^{\text {th }}$ day of curing. The results show formation of a new hydration compound, Bavenite in both bacterial mortars.

The XRD analysis of the OPC mortars confirms that microbial biocementation introduces a new cementitious product, Bavenite, $\mathrm{Al}_{2} \mathrm{Be}_{2} \mathrm{Ca}_{4} \mathrm{H}_{2} \mathrm{O}_{28} \mathrm{Si}_{9}$, which is absent in the control mortar, OPC- $\mathrm{H}_{2} \mathrm{O}\left(\mathrm{H}_{2} \mathrm{O}\right)$, but present in the microbial mortars, OPC-LB (LB) and OPC-BM (BM) at $2.53 \%$ and $1.33 \%$, respectively. Calcite, $\mathrm{CaCO}_{3}$, is significantly more in OPC-BM (BM) and OPC-LB (LB) at $10.27 \%$ and $10.23 \%$, respectively, as compared with $0.64 \%$ in OPC$\mathrm{H}_{2} \mathrm{O}\left(\mathrm{H}_{2} \mathrm{O}\right)$. This relates with improved calcite $\left(\mathrm{CaCO}_{3}\right)$ deposits and depleted Portlandite, $\mathrm{Ca}(\mathrm{OH})_{2}$, in microbial mortars as seen in SEM morphological images in Figures 3 and 4. XRD diffractograms also confirmed the same as depicted in Figures 5(a)-5(c). The depleted $\mathrm{Ca}(\mathrm{OH})_{2}$ in microbial mortars compared to that in control mortars could be attributed to the binding of $\mathrm{Ca}^{2+}$ with the microbial precipitated $\mathrm{CO}_{3}{ }^{2-}$.

More densification of C-S-H in microbial mortars than in control mortar is observed in SEM micrographs due to the high percentage of both Bavenite, $\mathrm{Al}_{2} \mathrm{Be}_{2} \mathrm{Ca}_{4} \mathrm{H}_{2} \mathrm{O}_{28} \mathrm{Si}_{9}$, and Dellaite, $\mathrm{Ca}_{6} \mathrm{H}_{2} \mathrm{O}_{13} \mathrm{Si}_{3}$, either individually or as combined in OPC-BM (BM) and OPC-LB (LB) compared to in OPC- $\mathrm{H}_{2} \mathrm{O}\left(\mathrm{H}_{2} \mathrm{O}\right)$ as depicted in Figures 5(a)-5(c) and summarized in Table 2. The XRD quantifications confirm the presence of calcite as well as more C-S-H in microbial mortars. These depositions in the pores maximized the packing density of cement mortar consequently improving the mortar's physicochemical and mechanical properties.

3.3. Flexural Strength Gain. The percent gain flexural strength results obtained at $14^{\text {th }}, 28^{\text {th }}$, and $56^{\text {th }}$ day of curing are given in Figure 6.

Table 3 summarizes the significant difference in flexural strength gain between the control and microbial mortars across $2^{\text {nd }}, 7^{\text {th }}, 14^{\text {th }}, 28^{\text {th }}$, and $56^{\text {th }}$ day of curing.

Across all mortar categories, for both Lysinibacillus sphaericus and Bacillus megaterium there was no significant difference $\left(T_{\text {calc }}=0.5, p=0.05\right)$ in their flexural strengths at $2^{\text {nd }}$ and $7^{\text {th }}$ day of curing. The flexural strength across all mortar categories for both bacteria under study increased with an increase in curing age as depicted in Figure 6. Considering the control and the microbial mortars across all the test bacteria mortars, the flexural strength increase was higher and more statistically significant between the $14^{\text {th }}$ and $28^{\text {th }}$ day than between the $28^{\text {th }}$ and $56^{\text {th }}$ day of curing as demonstrated by the results in Table 3. However, among the microbial mortars, flexural strength appears to be influenced more by the type of the bacteria as well as the preparation or curing regime than the curing age.

There was a statistically significant difference in flexural strength across all microbial mortar categories between different days of curing, as well as between the Lysinibacillus sphaericus mortars and Bacillus megaterium mortars as depicted in Table 3. This could imply the fact that the formation of C-S-H increases with curing age and that introduction of the microbial solution, either during preparation of mortars or as the curing regime enhances the formation of $\mathrm{C}-\mathrm{S}-\mathrm{H}$ results in improved flexural strength.

The flexural strength improvement for mortars of both bacteria under study was more pronounced when the microbial solution was used as the mix water than as the curing regime. Across all curing ages, OPC-LB (LB) exhibited the highest percentage gain in flexural strength than the other mortar categories. The highest percent flexural strength gain was observed at the $56^{\text {th }}$ day of curing at $37.0 \%$. There was observed a statistically significant difference in percent flexural strength gain both from one curing age to another as well from one microbial mortar category to another for all microbial mortar 


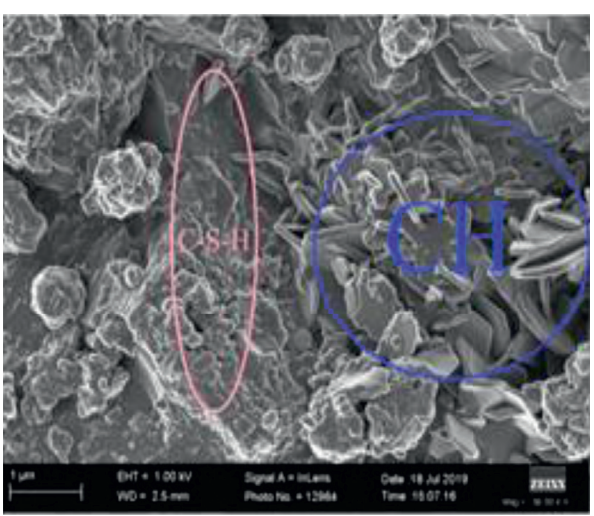

(a)

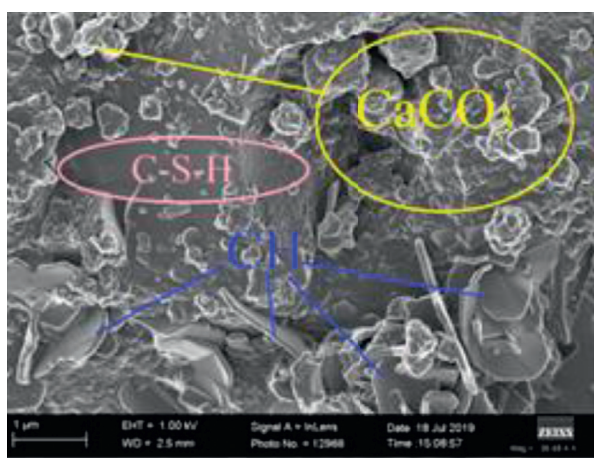

(c)

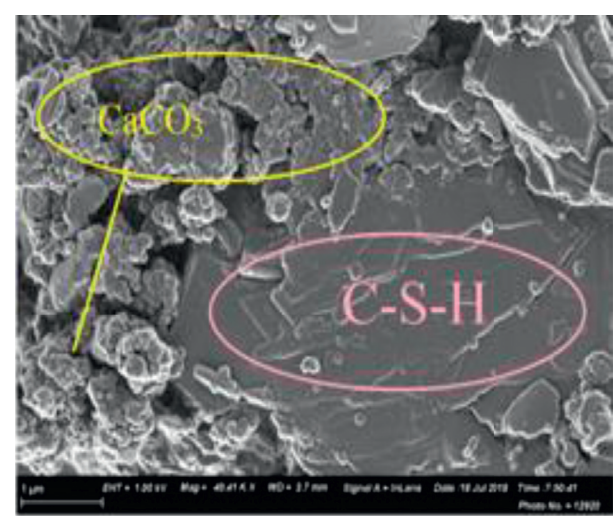

(b)

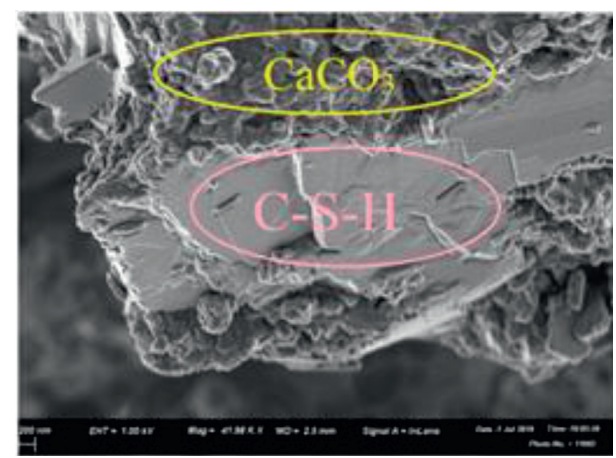

(d)

FIgure 3: SEM analysis for (a) OPC- $\mathrm{H}_{2} \mathrm{O}\left(\mathrm{H}_{2} \mathrm{O}\right)$, (b) OPC- $\mathrm{H}_{2} \mathrm{O}(\mathrm{LB})$, (c) OPC-LB $\left(\mathrm{H}_{2} \mathrm{O}\right)$, and (d) OPC-LB (LB).

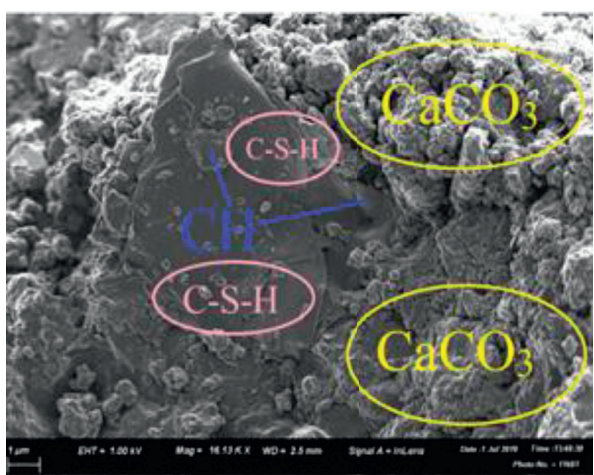

(a)

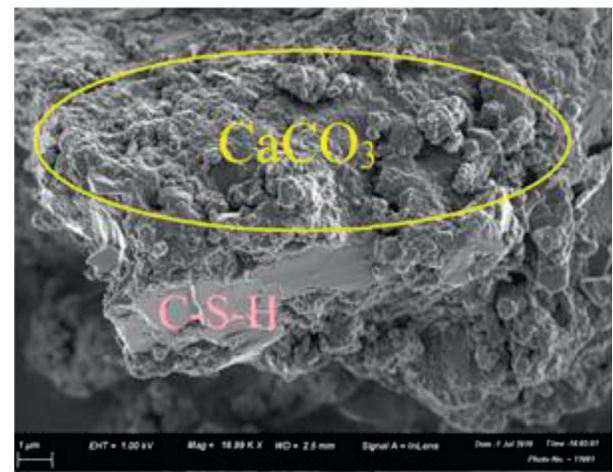

(b)

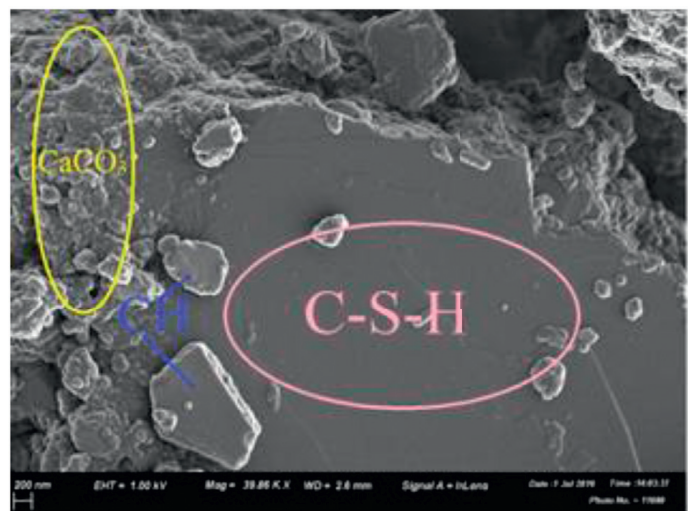

(c)

Figure 4: SEM analysis for (a) OPC- $\mathrm{H}_{2} \mathrm{O}(\mathrm{BM})$, (b) OPC-BM $\left(\mathrm{H}_{2} \mathrm{O}\right)$, and (c) OPC-BM (BM). 
TABLE 2: XRD (\% w/w \pm SD values) summary for hydrated OPC microbial mortars prepared and cured in respective bacteria against control OPC mortar after $28^{\text {th }}$ day of curing.

\begin{tabular}{|c|c|c|c|}
\hline \multirow{2}{*}{ Hydration compound } & \multicolumn{3}{|c|}{ Mortar category $(\% \mathrm{w} / \mathrm{w} \pm \mathrm{SD})$} \\
\hline & $\mathrm{OPC}-\mathrm{H}_{2} \mathrm{O}\left(\mathrm{H}_{2} \mathrm{O}\right)$ & OPC-LB (LB) & OPC-BM (BM) \\
\hline \multicolumn{4}{|c|}{ Bavenite, $\mathrm{Al}_{2} \mathrm{Be}_{2} \mathrm{Ca}_{4} \mathrm{H}_{2} \mathrm{O}_{28} \mathrm{Si}_{9}$} \\
\hline Sample 1 & - & 2.55 & 1.36 \\
\hline Sample 2 & - & 2.52 & 1.33 \\
\hline Sample 3 & - & 2.51 & 1.29 \\
\hline Average & - & 2.53 & 1.33 \\
\hline Std. dev. & - & \pm 0.02 & \pm 0.03 \\
\hline$\%$ Average \pm SD & - & $2.53 \pm 0.02$ & $1.33 \pm 0.03$ \\
\hline \multicolumn{4}{|l|}{ Dellaite, $\mathrm{Ca}_{6} \mathrm{H}_{2} \mathrm{O}_{13} \mathrm{Si}_{3}$} \\
\hline Sample 1 & 83.89 & 83.49 & 84.21 \\
\hline Sample 2 & 83.95 & 83.47 & 84.18 \\
\hline Sample 3 & 83.94 & 83.45 & 84.16 \\
\hline Average & 83.93 & 83.47 & 84.18 \\
\hline Std. dev. & \pm 0.03 & \pm 0.02 & \pm 0.02 \\
\hline$\%$ Average \pm SD & $83.93 \pm 0.03$ & $83.47 \pm 0.02$ & $84.18 \pm 0.02$ \\
\hline \multicolumn{4}{|l|}{ Calcite, $\mathrm{CaCO}_{3}$} \\
\hline Sample 1 & 0.67 & 10.26 & 10.24 \\
\hline Sample 2 & 0.63 & 10.22 & 10.29 \\
\hline Sample 3 & 0.61 & 10.21 & 10.27 \\
\hline Average & 0.64 & 10.23 & 10.27 \\
\hline Std. dev. & \pm 0.02 & \pm 0.02 & \pm 0.02 \\
\hline$\%$ Average \pm SD & $0.64 \pm 0.02$ & $10.23 \pm 0.02$ & $10.27 \pm 0.02$ \\
\hline \multicolumn{4}{|l|}{ Portlandite, $\mathrm{CaH}_{2} \mathrm{O}_{2}$} \\
\hline Sample 1 & 15.43 & 3.86 & 4.21 \\
\hline Sample 2 & 15.48 & 3.82 & 4.17 \\
\hline Sample 3 & 15.49 & 3.84 & 4.19 \\
\hline Average & 15.47 & 3.84 & 4.19 \\
\hline Std. dev. & \pm 0.03 & \pm 0.02 & \pm 0.02 \\
\hline$\%$ Average \pm SD & $15.47 \pm 0.03$ & $3.84 \pm 0.02$ & $4.19 \pm 0.02$ \\
\hline
\end{tabular}

$\mathrm{OPC} \mathrm{H}_{2} \mathrm{O}$

(coupled twotheta/theta)

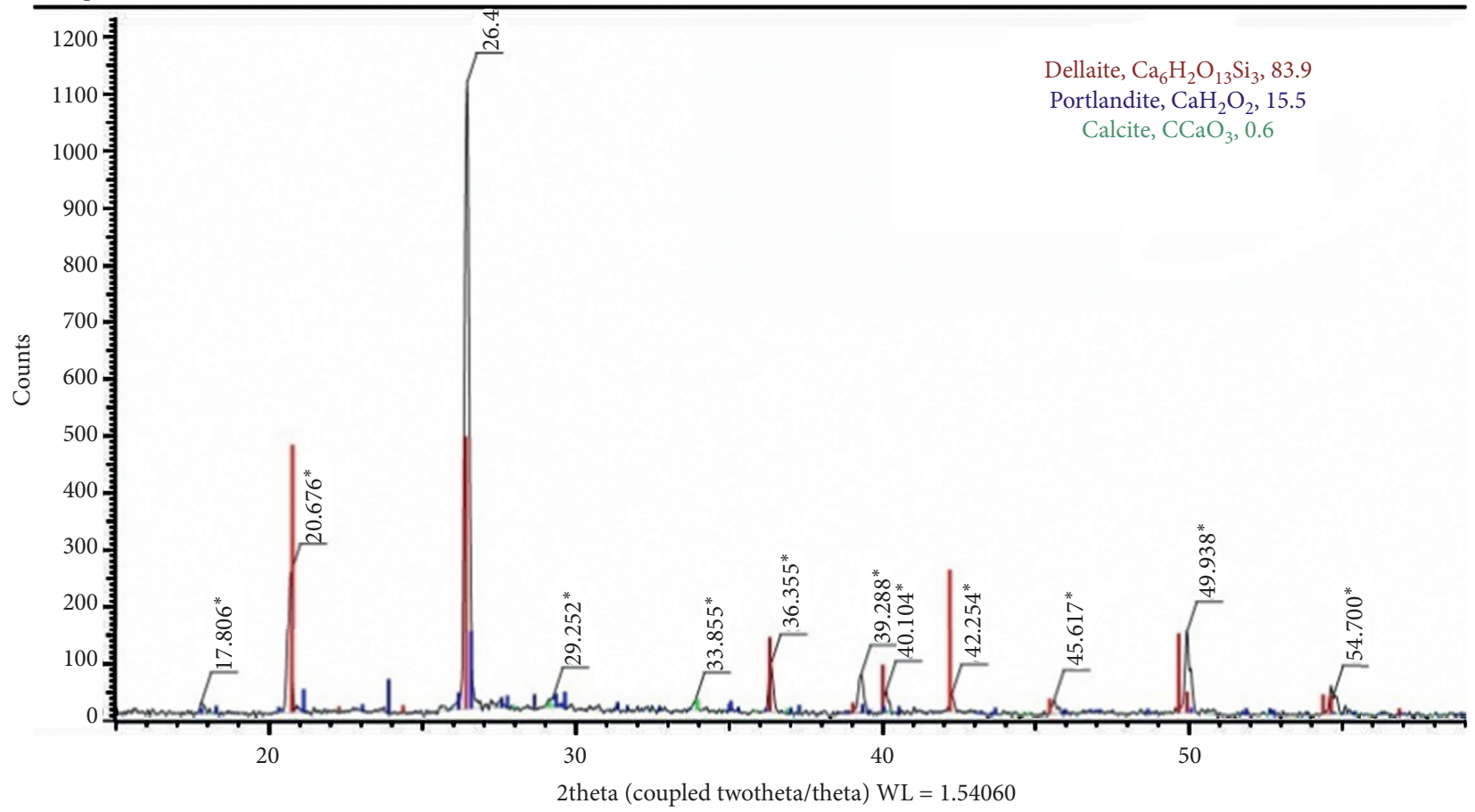

(a)

Figure 5: Continued. 
OPC LB

(coupled twotheta/theta)

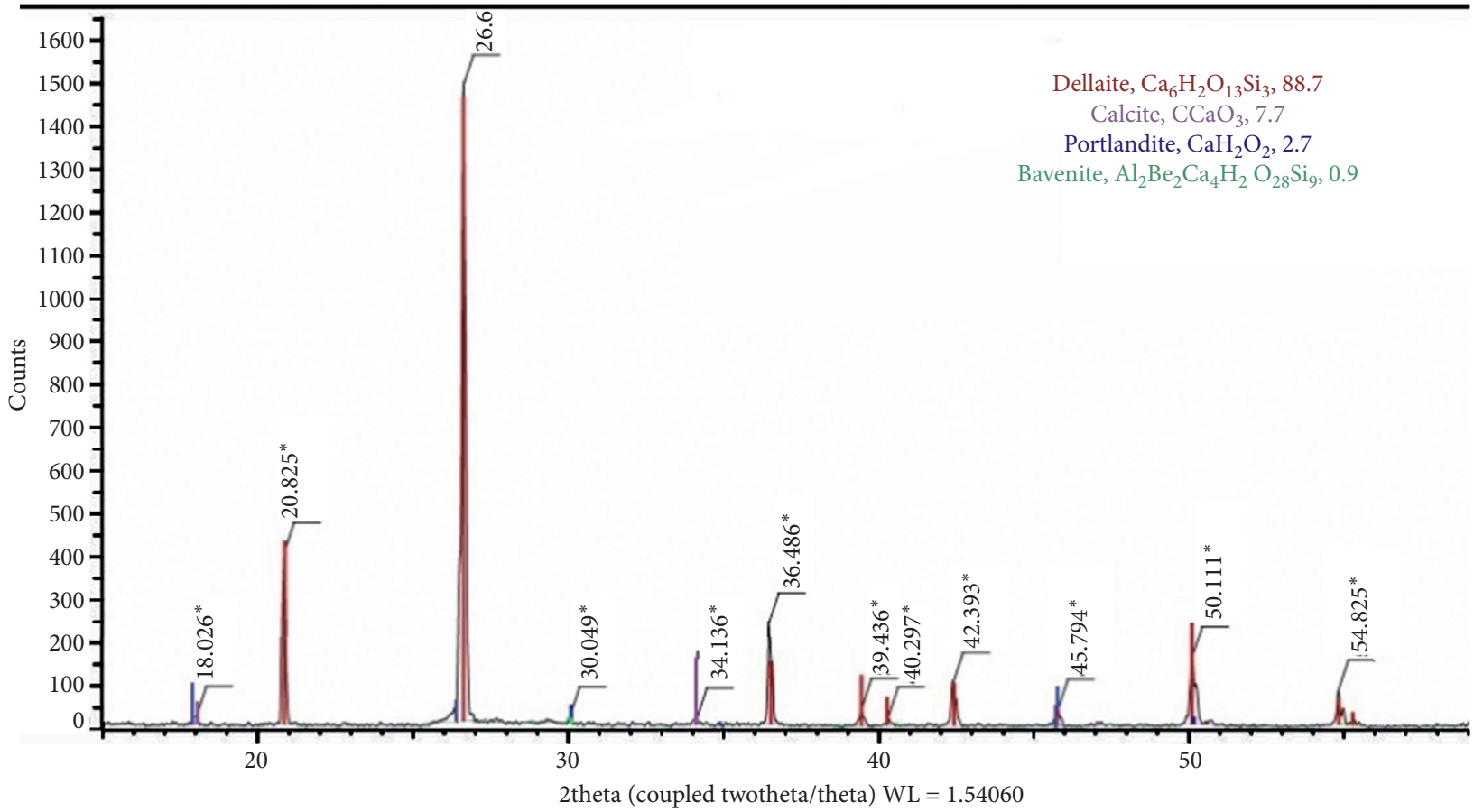

(b)

OPC BM

(coupled twotheta/theta)

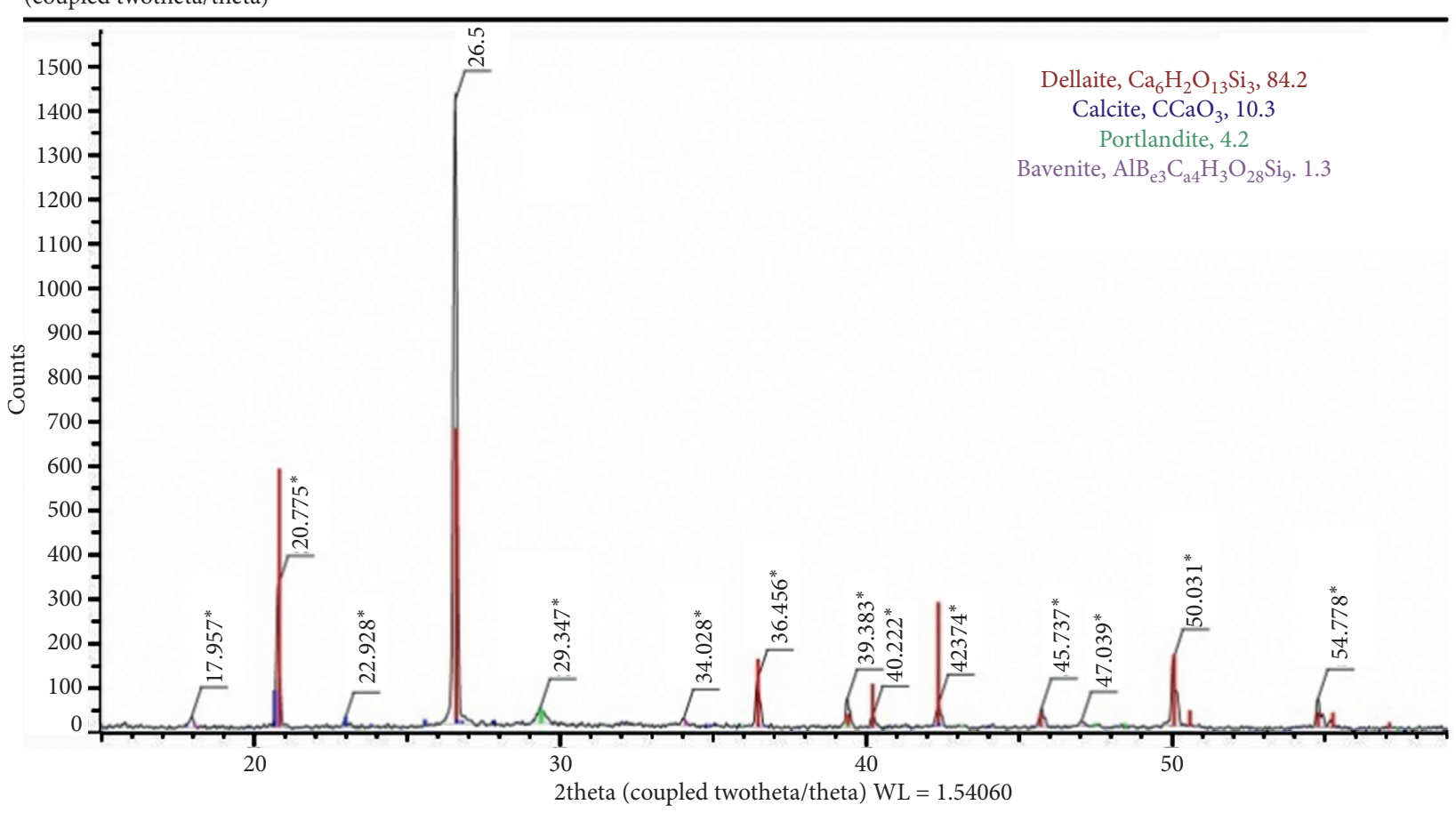

(c)

Figure 5: (a) Diffractograms for OPC- $\mathrm{H}_{2} \mathrm{O}\left(\mathrm{H}_{2} \mathrm{O}\right)$. (b) Diffractograms for OPC-LB (LB). (c) Diffractograms for OPC-BM (BM).

categories as shown in Table 3 and Figure 7 , respectively. The increase in flexural strength is attributed to the materials precipitated by the Lysinibacillus sphaericus being involved in the hydration process forming $\mathrm{C}-\mathrm{S}-\mathrm{H}$ responsible for strength development. The added $\mathrm{Ca}^{2+}$ together with calcium acetate, in presence of the microbial cell-wall as the nucleation site readily combine with the precipitated $\mathrm{CO}_{3}{ }^{2-}$ and crystallizes out as $\mathrm{CaCO}_{3}$ which 


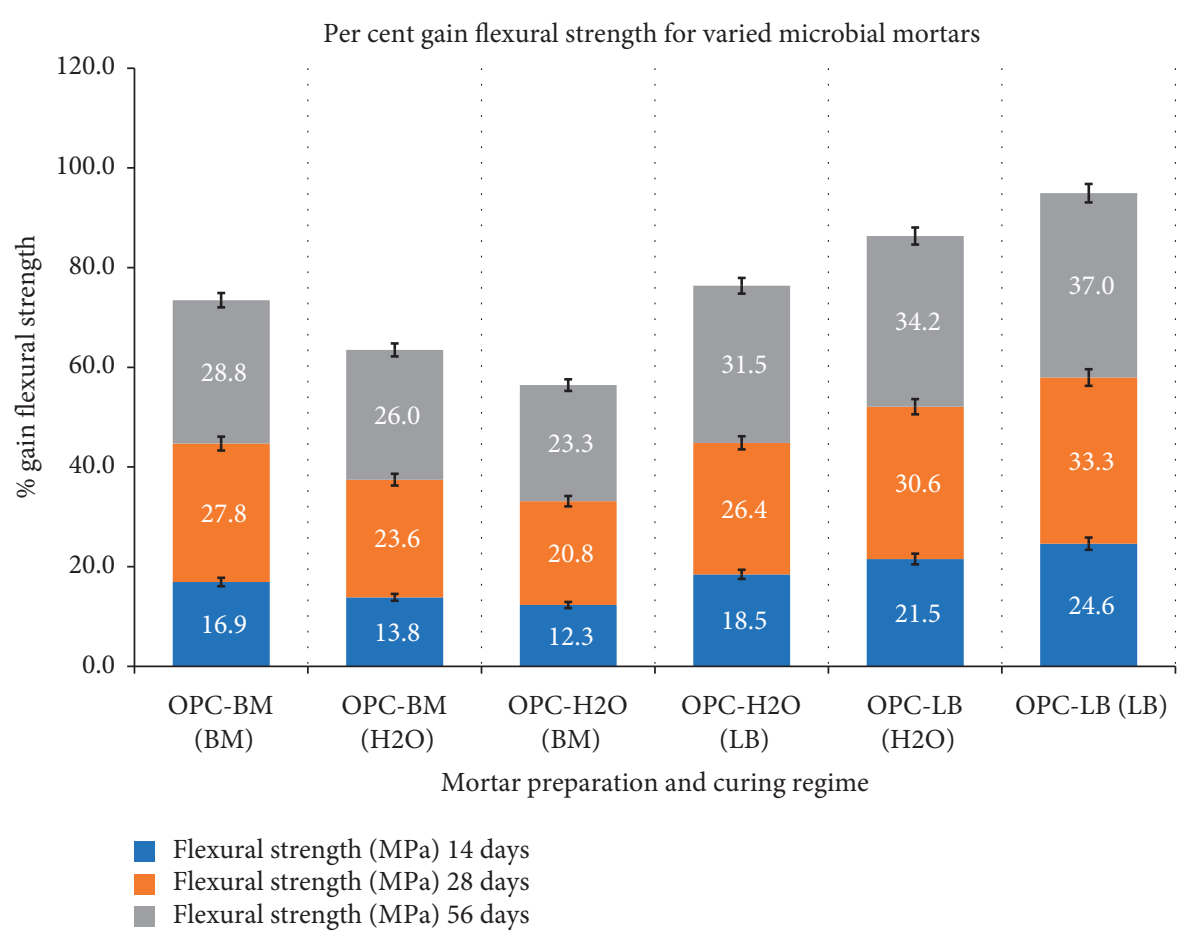

Figure 6: Percent gain flexural strength of test mortars at $14^{\text {th }}, 28^{\text {th }}$, and $56^{\text {th }}$ day of curing.

TABLE 3: $\mathrm{T}_{\text {calc. }}$ values summary for microbial mortars against control mortar and among varied microbial mortar categories flexural strength across $2^{\text {nd }}, 7^{\text {th }}, 14^{\text {th }}, 28^{\text {th }}$, and $56^{\text {th }}$ day of curing $\left(T_{\text {crit. }}=0.5, p=0.05\right)$.

\begin{tabular}{|c|c|c|c|c|c|}
\hline \multirow[b]{2}{*}{ Mortar categories } & \multicolumn{5}{|c|}{$T_{\text {calc. }}$ values } \\
\hline & $\begin{array}{c}2^{\text {nd }} \text { day } \\
T_{\text {calc }} \times 10^{-1}\end{array}$ & $\begin{array}{c}7^{\text {th }} \text { day } \\
T_{\text {calc }} \times 10^{-1} \\
\end{array}$ & $\begin{array}{c}14^{\text {th }} \text { day } \\
T_{\text {calc }} \times 10^{-5}\end{array}$ & $\begin{array}{c}28^{\text {th }} \text { day } \\
T_{\text {calc }} \times 10^{-5}\end{array}$ & $\begin{array}{c}56^{\text {th }} \text { day } \\
T_{\text {calc }} \times 10^{-5}\end{array}$ \\
\hline OPC- $\mathrm{H}_{2} \mathrm{O}\left(\mathrm{H}_{2} \mathrm{O}\right)$ vs. OPC- $\mathrm{H}_{2} \mathrm{O}(\mathrm{LB})$ & 5.0 & 5.0 & 13.7908 & 6.8664 & 0.4725 \\
\hline OPC- $\mathrm{H}_{2} \mathrm{O}\left(\mathrm{H}_{2} \mathrm{O}\right)$ vs. OPC-LB $\left(\mathrm{H}_{2} \mathrm{O}\right)$ & 5.0 & 5.0 & 46.4869 & 4.9426 & 1.2694 \\
\hline OPC- $\mathrm{H}_{2} \mathrm{O}\left(\mathrm{H}_{2} \mathrm{O}\right)$ vs. OPC-LB (LB) & 5.0 & 5.0 & 26.6329 & 6.1408 & 2.4344 \\
\hline OPC- $\mathrm{H}_{2} \mathrm{O}\left(\mathrm{H}_{2} \mathrm{O}\right)$ vs. OPC- $\mathrm{H}_{2} \mathrm{O}(\mathrm{BM})$ & 5.0 & 5.0 & 4.9845 & 3.7064 & 3.9136 \\
\hline OPC- $\mathrm{H} 2 \mathrm{O}\left(\mathrm{H}_{2} \mathrm{O}\right)$ vs.OPC-BM $\left(\mathrm{H}_{2} \mathrm{O}\right)$ & 5.0 & 5.0 & 67.1730 & 9.4017 & 1.0106 \\
\hline OPC- $\mathrm{H}_{2} \mathrm{O}\left(\mathrm{H}_{2} \mathrm{O}\right)$ vs. OPC-BM (BM) & 5.0 & 5.0 & 1.2815 & 1.2371 & 0.6787 \\
\hline OPC $-\mathrm{H}_{2} \mathrm{O}(\mathrm{BM})$ vs. OPC $-\mathrm{H}_{2} \mathrm{O}(\mathrm{LB})$ & 5.0 & 5.0 & 302.5298 & 302.5298 & 133.2461 \\
\hline OPC-BM $\left(\mathrm{H}_{2} \mathrm{O}\right)$ vs. OPC-LB $\left(\mathrm{H}_{2} \mathrm{O}\right)$ & 5.0 & 5.0 & 535.0033 & 38.8954 & 133.2461 \\
\hline OPC-BM (BM) vs. OPC-LB (LB) & 5.0 & 5.0 & 22.3619 & 402.4947 & 436.5515 \\
\hline
\end{tabular}

stimulate and accelerate the hydration of C-S-H $[31,32,42]$.

In this study, it has been found that Bacillus megaterium and the Lysinibacillus sphaericus biomineralization process enhance the flexural strength. The enhanced MICP process could also be ascribed to the metabolic conversion of the organic acetate added as a microbial feed in form of calcium acetate which was aerobically oxidized under improved alkaline conditions by these ureolytic alkaliphilic Bacillus spp. Lysinibacillus sphaericus MICP precipitate is more crystalline while that from Bacillus megaterium is more amorphous as shown in Figures 3 and 4's SEM images, respectively. Perhaps, the more the crystalline MICP deposits, the more and the better the $\mathrm{C}-\mathrm{S}-\mathrm{H}$ bonding resulting in enhanced flexural strength gain by Lysinibacillus sphaericus which deposits relatively more crystalline precipitate than Bacillus megaterium which deposits more amorphous precipitates [3, 4, 31, 42]. The amorphous MICP deposition serves as a barrier as it fills any pore/pathway reducing porosity and thus improves impermeability and ingress resistance. Perhaps, this difference in MICP crystallinity and the quantity between the two test bacteria explain why Lysinibacillus sphaericus is a better flexural strength enhancer while Bacillus megaterium improves impermeability thus a better chloride ingress inhibitor. Similar observations have been made by other researchers, Azadi et al. [6], Chahal et al. [31], Abo-El-Enein et al. [43], and Kim et al. [44] though using other bacteria species. The MICP precipitation occurs according to the following equation $[1,32]$ : 


$$
\begin{aligned}
\mathrm{CH}_{3} \mathrm{COO}^{1-}+2 \mathrm{O}_{2} & \longrightarrow 2 \mathrm{CO}_{2}+\mathrm{OH}^{1-}+\mathrm{H}_{2} \mathrm{O} \\
\mathrm{CO}_{2}+\mathrm{OH}^{1-} & \longrightarrow \mathrm{HCO}_{3}{ }^{1-} \\
\mathrm{HCO}_{3}{ }^{1-}+\mathrm{OH}^{1-} & \longrightarrow \mathrm{CO}_{3}{ }^{2-}+\mathrm{H}_{2} \mathrm{O} \\
\text { Bacterial Cell }-\mathrm{Ca}^{2+}+\mathrm{CO}_{3}{ }^{2-} & \longrightarrow \mathrm{Cell}-\mathrm{CaCO}_{3}
\end{aligned}
$$

Bacillus megaterium and Lysinibacillus sphaericus bacteria cause densification of the mortar due to increased cement products, $\mathrm{CaCO}_{3}, \mathrm{CSH}$, and ettringite.

\subsection{Chloride Ingress}

3.4.1. Chloride Profiling. Results for chloride ingress into the test microbial OPC mortars determined at the varied depth of cover within the mortar are presented in Figures 7 and 8 for Lysinibacillus sphaericus and Bacillus megaterium, respectively.

In all cases, the bacterial presence affected the presence of the $\mathrm{Cl}^{-}$. As observed, the $\mathrm{Cl}^{-}$ingress was sharper across all penetration depths in OPC $-\mathrm{H}_{2} \mathrm{O}\left(\mathrm{H}_{2} \mathrm{O}\right)$ than in all microbial mortars up to the $60 \mathrm{~mm}$ and $40 \mathrm{~mm}$ along the penetration depths, respectively. Perhaps this is due to the lower chloride binding capacity in OPC- $\mathrm{H}_{2} \mathrm{O}$ $\left(\mathrm{H}_{2} \mathrm{O}\right)$ than in microbial mortars [1]. This could be attributed to the increased content of $\mathrm{C}-\mathrm{S}-\mathrm{H}$ and $\mathrm{CAH}$ gels that seal the microbial mortar pore connectivity as observed from SEM results above. The reduction in chloride ion in microbial mortars prepared and cured using microbial solution was higher than in the ones either prepared or cured in microbial solutions. This could also be attributed to more MICP precipitates in mortar hydrates, further decreasing the permeability. The trend correlates with that observed by Mutitu et al. [1], Chahal et al. [31], and Nosouhian et al. [45], although involving other types of Bacillus spp bacteria. The authors attributed higher chloride ingress in $\mathrm{OPC}-\mathrm{H}_{2} \mathrm{O}\left(\mathrm{H}_{2} \mathrm{O}\right)$ than in microbial mortars to continuous and interlinked voids through which the ions ingress.

3.4.2. Chloride Apparent Diffusivity Coefficients. The results obtained from the chloride error function fitting curve for selected mortars OPC- $\mathrm{H}_{2} \mathrm{O}\left(\mathrm{H}_{2} \mathrm{O}\right)$, OPC-BM (BM), and OPC-LB (LB) are summarized in Table 4 showing $D_{\text {app }}$ and $D_{\text {mig }}$ with corresponding chloride surface concentration $\left(C_{\mathrm{s}}\right)$ and $r^{2}$ values of the test mortars from the two bacteria under study using $3.5 \%$ by mass sodium chloride solution.

OPC-BM (BM) and OPC-LB (LB) mortars exhibited the lowest apparent diffusion coefficient $\left(D_{\text {app }}\right)$ compared to the other microbial mortars in both BM and LB mortar categories. With low chloride ingress, low $D_{\text {app }}$ values were observed. OPC- $\mathrm{H}_{2} \mathrm{O}\left(\mathrm{H}_{2} \mathrm{O}\right)$ mortar had the highest $D_{\text {app }}$ value. Lower chloride $D_{\text {app }}$ values were demonstrated by Bacillus megaterium across all mortar categories than Lysinibacillus sphaericus mortars. Perhaps Bacillus megaterium could be a suitable internal and external crack healing bacterium than Lysinibacillus sphaericus bacteria. This could

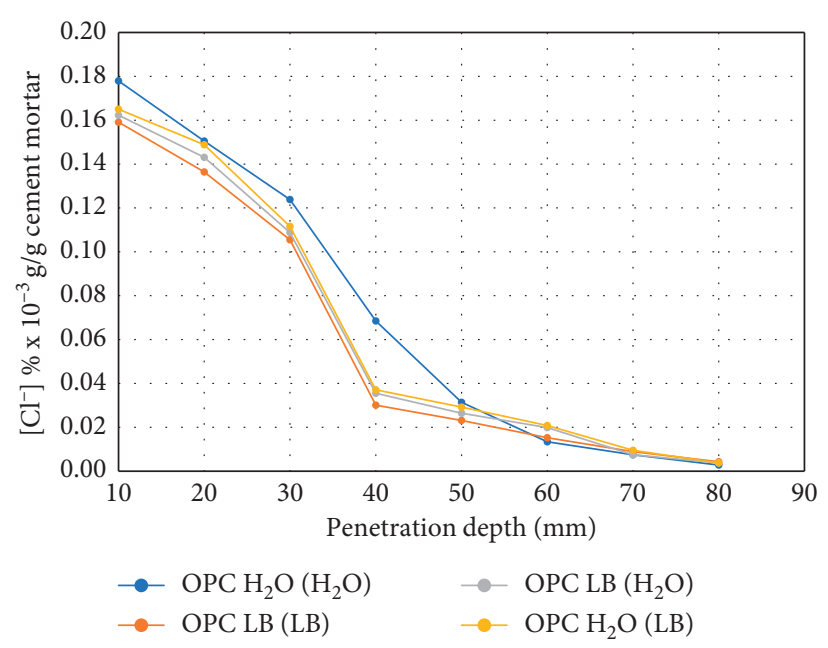

Figure 7: Chloride ion concentration at different depth of penetration for control OPC and varied Lysinibacillus sphaericus microbial mortars.

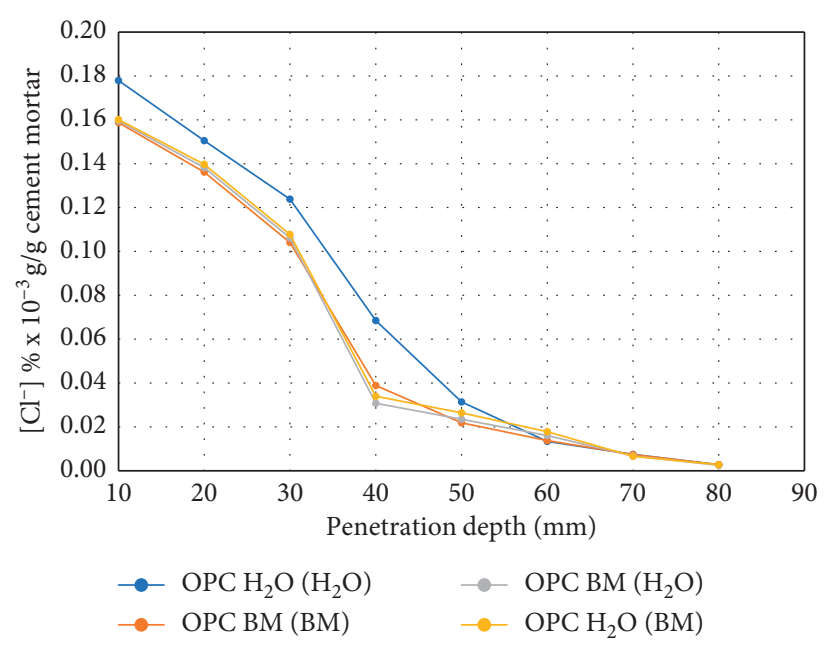

FIgURE 8: Chloride ion concentration at different depth of penetration for control OPC and varied Bacillus megaterium microbial mortars.

be attributed to the MICP deposits present in the microbial mortars which upon reacting with hydration cement products results in additional cementitious material that makes the mortar denser with increased resistivity to $\mathrm{Cl}^{-}$ ingress and lower chloride diffusivity.

\section{Conclusions}

(1) Both Bacillus megaterium and Lysinibacillus sphaericus have the ability to precipitate calcium carbonate that improves both flexural strength as well as the pore structure and thus lowering chloride ingress.

(2) Flexural strength of the mortar has a positive correlation with $\mathrm{CaCO}_{3}$ precipitation, for both Bacillus 
Table 4: $C_{\mathrm{S}}, D_{\text {mig }}, D_{\text {app }}$, and $r^{2}$-values for different microbial mortars in $\mathrm{NaCl}$.

\begin{tabular}{lccc}
\hline Mortar type & $C_{\mathrm{s}}$ & $D_{\text {mig. }} \times 10^{-9}\left(\mathrm{~m}^{2} / \mathrm{s}\right)$ & $D_{\text {app }} \times 10^{-10}\left(\mathrm{~m}^{2} / \mathrm{s}\right)$ \\
\hline OPC- $\mathrm{H}_{2} \mathrm{O}\left(\mathrm{H}_{2} \mathrm{O}\right)$ & 0.2255 & 5.6052 & 2.8430 \\
OPC-BM $(\mathrm{BM})$ & 0.1997 & 5.2161 & 2.6456 \\
OPC-BM $\left(\mathrm{H}_{2} \mathrm{O}\right)$ & 0.1965 & 5.3982 & 2.7380 \\
OPC- $\mathrm{H}_{2} \mathrm{O}(\mathrm{BM})$ & 0.2000 & 5.4596 & 2.7691 \\
OPC-LB (LB) & 0.2016 & 5.2764 & 2.6762 \\
OPC-LB $\left(\mathrm{H}_{2} \mathrm{O}\right)$ & 0.2033 & 5.4801 & 2.7796 \\
OPC- $\mathrm{H}_{2} \mathrm{O}(\mathrm{LB})$ & 0.2099 & 5.5213 & 2.8005 \\
\hline
\end{tabular}

megaterium and Lysinibacillus sphaericus bacteria. This was exhibited by the higher strengths in microbial mortars cured in cultured solutions than those cured in distilled water.

(3) Lower chloride ingress was observed in both Bacillus megaterium and Lysinibacillus sphaericus bacteria microbial mortars prepared and cured using cultured solutions than those cured in distilled water. This was exhibited by the lower $D_{\text {app }}$ values in microbial mortars cured in cultured solutions than those cured in distilled water. Bacillus megaterium bacteria improved the chloride ingress resistivity more than the Lysinibacillus sphaericus bacteria.

(4) Lysinibacillus sphaericus bacteria improved flexural strength more than the Bacillus megaterium bacteria. This was demonstrated by the higher flexural strength as well as higher percent flexural strength gain across all mortar curing ages across all mortar categories than Bacillus megaterium mortars. Perhaps Lysinibacillus sphaericus could be a better flexural strength enhancer than Bacillus megaterium bacteria.

\section{Data Availability}

The data used to support the findings of this study are available from the corresponding author upon request.

\section{Conflicts of Interest}

The authors declare that they have no conflicts of interest.

\section{Acknowledgments}

The authors wish to acknowledge the support granted by various institutions during the experimentation and writing of this paper. The institutions gave access to scholarly repository and library materials, laboratory facilities, and disposables. The institutions include the University of Embu, Kenyatta University, and Savannah Cement Limited, all from Kenya, and the University of Pretoria, South Africa.

\section{References}

[1] D. K. Mutitu, O. M. Mulwa, J. M. Wachira, R. Mwirichia, J. K. Thiong'o, and J. M. Marangu, "Effects of biocementation on some properties of cement-based materials incorporating Bacillus species bacteria-a review," Journal of Sustainable Cement-Based Materials, vol. 8, no. 5, pp. 309-325, 2019.
[2] R. K. Verma, L. Chaurasia, and V. Bisht, "Bio-mineralization and bacterial carbonate precipitation in mortar and concrete," Journal of Bioscience and Bioengineering, vol. 1, pp. 5-11, 2015.

[3] C. X. Qian, X. N. Yu, and X. Wang, "A study on the cementation interface of bio-cement," Materials Characterization, vol. 59, pp. 1186-1193, 2018.

[4] M. Luo and C. Qjan, "Influences of bacteria-based self-healing agents on cementitious materials hydration kinetics and compressive strength," Construction and Building Materials, vol. 4, pp. 1132-1141, 2016.

[5] D. K. Mutitu, Diffusivity of Chloride and Sulphate Ions into Mortar Cubes Made Using Ordinary Portland and Portland Pozzolana Cement, Chemistry Department, Kenyatta University, Nairobi, Kenya, 2013.

[6] M. Azadi, M. Ghayoomi, N. Shamskia, and H. Kalantari, "Physical and mechanical properties of reconstructed biocemented sand," Soils and Foundations, vol. 57, no. 5, pp. 698-706, 2017.

[7] Z. H. Dong, W. Shi, and X. P. Guo, "Initiation and repassivation of pitting corrosion of carbon steel in carbonated concrete pore solution," Corrosion Science, vol. 53, no. 4, pp. 1322-1330, 2011.

[8] T. W. Zewdu and S. Esko, "Service life prediction of repaired structures using concrete recasting method: state-of-the-art," in Proceedings of the 11th International Scientific Conference on Modern Building Materials, Structures and Techniques, MBMST, pp. 1138-1144, Vilnius, Lithuania, May 2013.

[9] M. U. Khan, S. Ahmad, and H. J. Al-Gahtani, "Chloride induced corrosion of steel in concrete: an overview of chloride diffusion and prediction of corrosion initiation time," International Journal of Corrosion, vol. 2017, Article ID 5819202, 9 pages, 2017.

[10] M. V. A. Florea and H. J. H. Brouwers, "Chloride binding related to hydration products," Cement and Concrete Research, vol. 42, no. 2, pp. 282-290, 2012.

[11] P. K. Mehta, The Durability of Concrete in Marine Environment-A Review, the Performance of Concrete in a Marine Environment, Vol. 68, ACI Publications, Farmington Hills, MI, USA, 2011.

[12] M. Uysal, K. Yilmaz, and M. Ipek, "The effect of mineral admixtures on mechanical properties, chloride ion permeability and impermeability of self-compacting concrete," Construction and Building Materials, vol. 27, no. 1, pp. 263270, 2012.

[13] T. Luping and J. Gulikers, "On the mathematics of timedependent apparent chloride diffusion coefficient in concrete," Cement and Concrete Research, vol. 37, no. 4, pp. 589-595, 2007.

[14] J. M. Marangu, J. K. Thiong'o, and J. M. Wachira, "Chloride ingress in chemically activated calcined clay-based cement," Journal of Chemistry, vol. 2018, Article ID 1595230, 8 pages, 2018. 
[15] J. Wang, P. M. Basheer, S. V. Nanukuttan, and Y. Bai, "Influence of compressive loading on chloride ingress through concrete," in Proceedings of the Civil Engineering Research Association of Ireland (CERAI), pp. 28-29, Belfast, UK, August 2014.

[16] J. Crank, The Mathematics of Diffusion, Oxford University Press, New York, NY, USA, 2nd edition, 1975.

[17] L. Cheng and R. Cord-Ruwisch, "Selective enrichment and production of highly urease active bacteria by non-sterile (open) chemostat culture," Journal of Industrial Microbiology \& Biotechnology, vol. 40, no. 10, pp. 1095-1104, 2013.

[18] T. Rasheeduzzafar, E. S. Hussain, and S. S. Al-Saadoun, "Pore solution composition of hydrated cement pastes with reference to corrosion resistance performance of reinforcing steel in concrete," in Proceedings of the Vetch Middle East NACE Corrosion Conference, pp. 386-389, Manama, Bahrain, October 2004.

[19] J. M. Wachira, "Chloride ingress in pozzolana based cement," in Proceedings of the 7th Kenya Chemical Society International Conference, Kisumu, Kenya, October 2012.

[20] R. Alizadeh, J. J. Beaudoin, and L. Raki, "Mechanical properties of calcium silicate hydrates," Materials and Structures, vol. 44, no. 1, pp. 13-28, 2011.

[21] A. Dousti, M. Shekarchi, R. Alizadeh, and A. Taheri-Motlagh, "Binding of externally supplied chlorides in micro silica concrete under field exposure conditions," Cement and Concrete Composites, vol. 33, no. 10, pp. 1071-1079, 2011.

[22] C. Theodore and S. Karen, "Alkali fixation of CSH in blended cement pastes and its relation to alkali-silica reaction," Laboratory of Construction Materials, vol. 42, no. 8, pp. 1049-1054, 2012.

[23] P. Bamforth, "Concrete classification for RC structures exposed to marine and other salt-laden environments," in Proceedings of. 5th International Symposium on Structural Faults and Repair, pp. 31-40, Edinburgh, UK, June 2003.

[24] L. Bertolini, B. Elsner, P. Pedeferri, and R. Polder, Corrosion of Steel in Concrete: Prevention, Diagnosis, and Repair, WileyVCH Verlag GMbH \& Co. KGaA, Weinheim, Germany, 2004.

[25] N. De Belie and J. Wang, "Bacteria-based repair and selfhealing of concrete," Journal of Sustainable Cement-Based Materials, vol. 5, no. 1-2, pp. 35-56, 2016.

[26] V. N. Rao and T. Meena, "A review of carbonation study in concrete," IOP Conference Series: Materials Science and Engineering, vol. 263, no. 3, pp. 1-10, 2017.

[27] K. De Weerdt, D. Orsakova, A. C. A. Muller, C. K. Larsen, B. Pedersen, and M. R. Geiker, "Towards the understanding of chloride profiles in marine exposed concrete, the impact of leaching and moisture content," Construction and Building Materials, vol. 120, pp. 418-431, 2016.

[28] O. S. B. Al-Moudi, M. Masleuddin, and Y. A. B. Abdulal, "Role of chloride ions on expansion and strength reduction in plain and blended cement in sulphate environments," Construction and Building Material Journal, vol. 13, pp. 38-43, 2011.

[29] J. M. Wachira, J. K. Thiong'o, J. M. Marangu, and L. G. Muriithi, "Physicochemical performance of Portland-rice husk ash-calcined clay-dried acetylene lime sludge cement in sulphate and chloride media," Advances in Materials Science and Engineering, vol. 2019, Article ID 5618743, 12 pages, 2019.

[30] J. W. Jeffrey, P. Mondal, and C. M. Mideley, "Mechanisms of cement hydration," Cement and Concrete Research, vol. 41, no. 12, pp. 1208-1223, 2012.

[31] N. Chahal, R. Siddique, and A. Rajor, "Influence of bacteria on the compressive strength, water absorption and rapid chloride permeability of fly ash concrete," Construction and Building Materials, vol. 4, pp. 98-105, 2012.

[32] Y. C. Ersan, N. Hernandez-Sanabria, and N. De Belie, "Enhanced crack closure performance of microbial mortar through nitrate reduction," Cement and Concrete Research, vol. 70, pp. 159-170, 2015.

[33] EN 196-1, Cement Part 1: Composition, Specifications and Conformity Criteria for Common Cement, European Union Standards, Beckum, Germany, 2011.

[34] KS EAS 18-1, Kenya Standard Test Method for Oxides Specification of Hydraulic Cement, KEBS, Nairobi, Kenya, 2017.

[35] ASTM C 293, Standards of Flexural Strength of Concrete, Part 3, Effects of Variations in Testing Procedures, American Society for Testing and Materials, Elservier, London, UK, 1990.

[36] ASTM D7348, Standard Test Methods for Loss on Ignition (LOI) of Solid Combustion Residues, ASTM International, West Conshohocken, PA, USA, 2013.

[37] R. H. Bogue, "Chemistry of Portland cement," British Patent No. 5022, pp. 1927-1940, 1977.

[38] K. Scrivener, R. Snellings, and B. Lothenbach, A Practical Guide to Microstructural Analysis of Cementitious Materials, CRC Press, Boca Raton, FL, USA, 1st edition, 2017.

[39] ASTM C 1552, Standard Test Method for Determining Chloride Concentration using Chloride Ion-Selective Electrode, American Society for Testing and Materials, Elsevier, London, UK, 2005.

[40] C. Andrade, C. Castellote, C. Alonso, and C. Gonzalez, "Nonsteady-state chloride diffusion coefficients obtained from migration and natural diffusion tests," Materials and Structure, vol. 33, no. 1, pp. 21-28, 1999.

[41] M. S. Vekariya and J. Pitroda, "Bacterial concrete: a new era for the construction industry," International Journal of Engineering Trends and Technology (IJETT), vol. 4, pp. 9-16, 2013.

[42] H. Thiyagarajan, S. Maheswaran, M. Mapa et al., "Investigation of Bacterial activity on Compressive Strength of cement mortar in different curing Media," Journal of Advanced Concrete Technology, vol. 14, no. 4, pp. 125-133, 2016.

[43] S. A. Abo-El-Enein, A. H. Ali, A. H. Ali, F. N. Talkhan, and H. A. Abdel-Gawwad, "Application of microbial biocementation to improve the physico-mechanical properties of cement mortar," HBRC Journal, vol. 9, no. 1, pp. 36-40, 2013.

[44] H. K. Kim, S. J. Park, J. I. Han, and H. K. Lee, "Microbially mediated calcium carbonate precipitation on normal and lightweight concrete," Construction and Building Materials, vol. 38, pp. 1073-1082, 2013.

[45] F. Nosouhian, D. Mostofinejad, and H. Hasheminejad, "Concrete durability improvement in a sulphate environment using bacteria," Advances in Materials Science and Engineering, vol. 28, no. 1, Article ID 04015064, 2016. 